\title{
The Natural History and Treatment Guidelines of Cerebellar Liponeurocytoma-A Case Report
}

\author{
Or Cohen-Inbar, Euvgeni Vlodavsky, Menashe Zaaroor \\ Department of Neurosurgery, Rambam Maimondes Health care campus, Haifa, Israel \\ Faculty of Medicine, Technion Israel Institute of Technology, Haifa, Israel \\ E-mail: orcoheni@tx.technion.ac.il,or_coheni@rambam.health.gov.il \\ Received August 16, 2011; revised September 5, 2011; accepted September 20, 2011
}

\begin{abstract}
Background and Importance: Lipomatous medulloblastoma (cerebellar liponeurocytoma) is a rare cerebellar tumor, with only twenty-nine cases reported, considered a distinct variant of medulloblastoma. The few cases described support an indolent nature for this tumor. We aim at defining the optimum treatment strategy and long-term behavior for this tumor entity. Clinical presentation: A 74 years old male presented on September 2010 complaining of mild dizziness and headache slowly progressing over a few months. This gentleman was operated on at our department some 18 years ago for a right cerebellar hemispheral lesion, defined as a liponeurocytoma. This patient received no adjuvant treatment. Current magnetic resonance imaging (MRI) studies disclosed a right hemispheral cerebellar mass, locally recurrent in the original surgical tumor bed. Gross total resection of the tumor was accomplished through a suboccipital craniotomy, with complete resection of the lesion. The histopathological diagnosis was defined as cerebellar liponeurocytoma. No adjuvant therapy was given as initially, after the first operation. Currently, the patient is alive, fully alert with minimal neurological deficits, Barthel index 90, Kernofsky performance status of 90 and with no evidence of disease on neuroimaging. Conclusion: This patient portrays this tumor's natural history after surgical intervention with no adjuvant treatment, being the longest reported follow-up and recurrence. This distinct variant of medulloblastoma appears to have a uniquely favorable prognosis, even without adjuvant therapy. A complete surgical resection with close follow-up seems both sufficient and prudent.
\end{abstract}

Keywords: Natural History, Cerebellar Liponeurocytoma, Recurrence in 18 Years

\section{Introduction}

Medulloblastoma rarely occurs in adults. Greater than $70 \%$ of medulloblastoma cases occur in children [1]. This tumor represents less than one percent of all adult primary central nervous system (CNS) tumors. Most adult medulloblastoma are located in the cerebellar hemisphere, unlike the midline/vermis location most prevalent in the pediatric patients [2]. Medulloblastoma is well known as having multiple histopathological variants, including those displaying predominantly neuronal, glial, and/or myoid differentiation [3]. Sarkar et al. stated that the survival benefit in adults does not seem to be related to the histological variant (classical versus desmoplastic medulloblastoma variant), but rather to age [4]. The one exception to this statement is the lipomatous medulloblastoma variant, occurring almost exclusively in adults. The first lipomatous medulloblastoma (Cerebellar liponeurocytoma) was reported in 1978 by Bechtel et al. in a 44-year-old man [5]. Twenty-nine cases have been reported so far, under different names, such as "lipomatous medulloblastoma, lipidized medulloblastoma, neurolipocytoma, medullocytoma and lipomatous glioneurocytoma" [6] [Table 1]. Cerebellar liponeurocytoma has been recognized by the 2000 World Health Organization (WHO) classification of tumors of the central nervous system as a distinct clinicopathologic entity. In the new classification, this tumor subset is classified in the category of glioneuronal tumors grade I or II due to its favorable clinical behavior [7], even with incomplete resection or multicentric appearance [3]. Cerebellar liponeurocytoma is a neuroectodermal tumor consisting of both neuronal and glial elements. Immunohistochemistry for GFAP, synaptophysin and NSE are usually positive 
Table 1. Treatment of liponeurocytoma with radiotherapy/ death cross-tabulation.

\begin{tabular}{|c|c|c|c|c|}
\hline & & \multicolumn{2}{|c|}{ death } & \multirow{2}{*}{ Total } \\
\hline & & No & Yes & \\
\hline \multirow{2}{*}{ Radiotherapy } & No & 8 & 3 & 11 \\
\hline & Yes & 8 & 8 & 16 \\
\hline \multicolumn{2}{|l|}{ Total } & 16 & 11 & 27 \\
\hline
\end{tabular}

indicating the mixed glial and neuronal elements $[6,8,9]$. This tumor shares several features with the cerebellar medulloblastoma, which may include an origin from the periventricular matrix of the fourth ventricle or the external granular layer of the cerebellum. Recent work using cDNA expression array data suggests a relationship to central neurocytomas [10]. Microscopically, the tumor consists of small round to ovoid cells, with an eosinophilic scanty cytoplasm, extending between interspersed regions of lipidized cells that resemble mature adipocytes. Mitoses, areas of vascular proliferation and necrosis are all rare [1,6-9,11-16]. Mitotic activity is usually absent and the growth fraction, as reflected by the MIB-1 labeling index, is in the range of $1 \% \sim 3 \%[1,6-8,11-16]$.

The radiological appearance of this tumor on computed tomography (CT) is characterized as a hypodense mass with intermingled areas exhibiting the attenuation values of fatty tissue. $T_{1}$-weighted MR images feature this tumor as hypointense with scattered foci of hyperintense signal, displaying moderate contrast enhancement. $\mathrm{T}_{2}$-weighted MR images feature this tumor as slightly hyperintense relative to the cortex, with no edema present. Areas of fat density as assessed on CT scans and on MRI-T1WI help to distinguish this rare neoplasm from the more common adult medulloblastomas or ependymomas [17]. The aim of surgery is a gross total resection (GTR) of the tumor. In most of the cases reported there was a reasonable border between the tumor and surrounding tissue [17-19] and gross total removal of the tumor was feasible.

\section{Clinical Summery}

A 74 years old male presented to our institute on September 2010 describing an indolent, subjective feeling of dizziness and headache slowly progressing over the previous few months. Aside from a mild benign prostatic hyperplasia and hypercholesterolemia controlled medically, he did not suffer any other chronic illnesses. This gentleman was operated on at our institute some 18 years ago, for a right cerebellar hemispheral lesion. A GTR was achieved. The histopathological specimens were sent for consultation to professor John J. Kepes, who de- scribed it as "a tumor, whose neuroectodermal origin is probably not in doubt, having cellular areas to suggest differentiating medulloblastoma, elsewhere pilocytic astrocytoma, oligodendroglioma like foci and perivascular rosettes as seen in ependymomas, and striking large round spaces that I am sure were filled with fat". It was diagnosed as a medulloblastoma with lipoid differentiation (termed later as a liponeurocytoma). The patient received no adjuvant radiotherapy or chemotherapy and returned to a fully independent, working and productive life.

During the next few years the patient was followed as an outpatient, but dropped out of follow-up at some point. During the years 2004 and 2005 the patient presented to the emergency room twice reporting of a mild dizziness. A non-contrast enhanced computed tomography was performed, interpreted as normal with minimal chronic changes in the tumor bed. The patient was discharged without a neurosurgical consult, and returned to be fully active. A retrospective review of these scans raises suspicion of a local recurrence within the tumor bed, measuring $13 \mathrm{~mm}$ in its largest diameter (Figure 1).

Neurological examination: Mild dysdiadochokinesis, no ataxia, a negative Romberg sign.

Neuro-radiological findings: Current imaging as of September 2010 showed a non-enhancing mass within the tumor bed on tomography, measuring $43 \mathrm{~mm}$ in its largest diameter (Figure 2). The MRI appearance was described as a hypercellular partially cystic lesion, having delayed diffusion and a pathological enhancement. Signs of intralesional hemorrhage or calcifications were suspected and a mild peritumoral edema and multiple VRS described (Figure 3).

Surgical intervention: A right paramedian suboccipital craniotomy in the sitting position was performed. The tumor was grossly gray-reddish in color, partially attached to the surrounding tissue but well circumscribed. It was easily detachable from adjacent brain tissue and a GTR was achieved. The postoperative course was uneventful with the exception of an obstructive hydrocephalus secondary to peritumoral edema causing a nar-

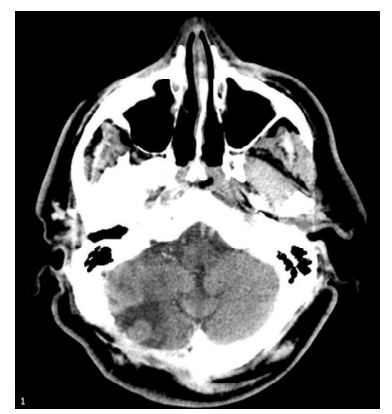

Figure 1. A non contrast enhanced computed tomography, 2005. 


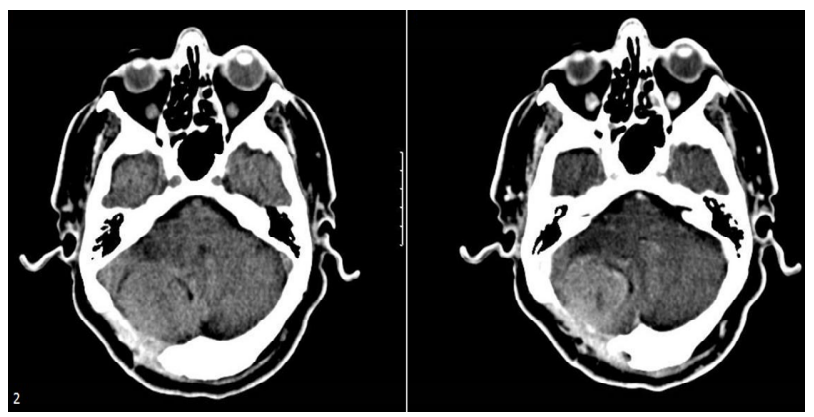

Figure 2. Computed tomography findings, both enahnced and not-enhanced by contrast, 2010.

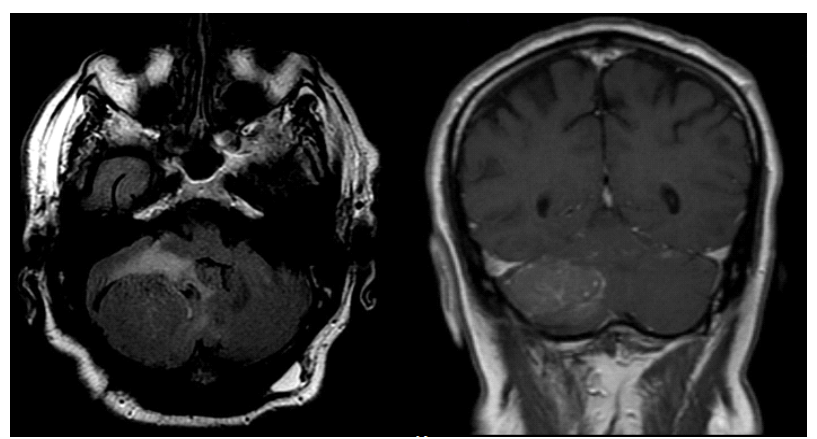

(a)

(b)

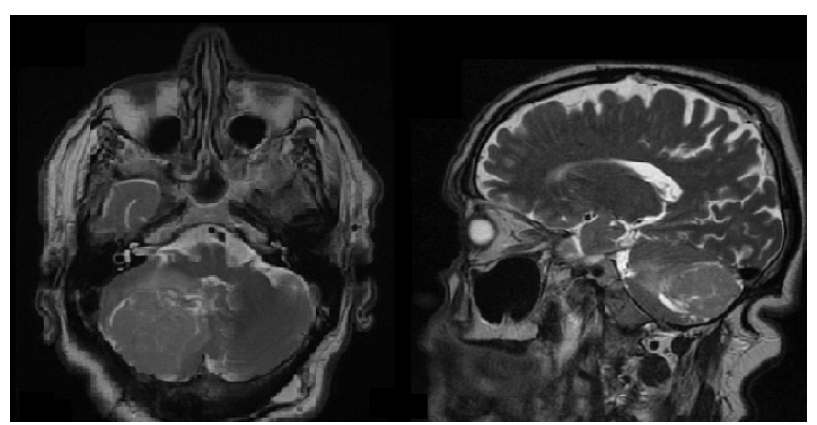

(c)

(d)

Figure 3. 2010 MRI, A. axial FLAIR, B. Coronal T1 with gadolinium, C. Axial T2, D. Sagittal T2.

rowing of the forth ventricle. This was managed with a ventricular drain for a few days after which the edema subsided and the hydrocephalus resolved. The patient was discharged shortly after.

Pathological findings: On histopathological sections, small round to oval cells characteristic of medulloblastoma were found in eosinophilic neuropil matrix, interspread with groups of lipocytes. Sections stained strongly positive for Neurontin, synaptophysin, only minimally positive for the proliferation marker Ki-67, estimated as less than $5 \%$ of the cells (Figure 4).

\section{Discussion}

Lipomatous differentiation of central nervous system

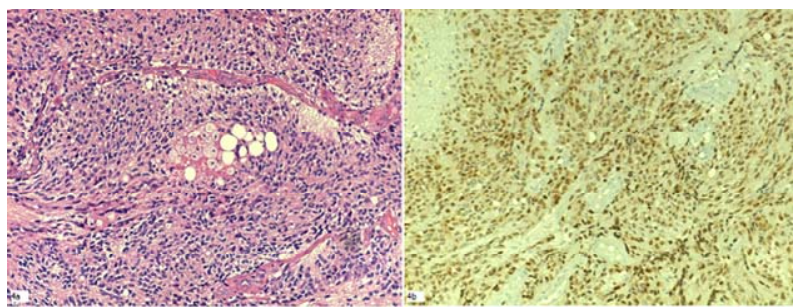

(a)

(b)

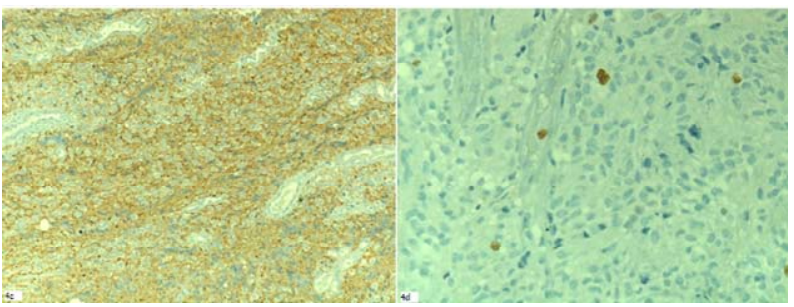

(c)

(d)

Figure 4. Microscopic and immunohistochemical features of lipomatous medulloblastoma. (a) small round and oval cells of medulloblastoma in eosinophilic neuropil matrix and the group of lipocytes; Hematoxylin and eosin, x100; (b) strongly positive immunostain for NeuN; immunoperoxidase, x100; (c) positive immunostaining for synaptophysin; immunoperoxidase, $x 100$; (d) only few cells are positive for proliferation marker Ki-67, immunoperoxidase, x200.

tumors is rare. Among astrocytic neoplasias, lipomatous differentiation is best known to be present in pleomorphic xanthoastrocytoma [20]. Multivacuoler lipidization is also observed in glioblastoma multiforme, ependymoma and primitive neuroectodermal cerebral tumors [21-24]. Cerebellar liponeurocytoma is a rare cerebellar tumor, with only 29 cases reported under many different names [Table 2]. Although the few cases described support the relatively benign nature of this lesion, the optimum treatment strategy and long-term follow-up and prognosis still has to be defined [8]. Reviews published in the literature report a 5-year survival rate of $81 \%$ [6, 19], with recurrence appearing as late as 15 years after surgery, although most appear sooner [1,7,8-13,13-14, 25-30]. A caveat to this figure stems from the low number of patients per report (most are case reports) and the inconsistency in pathological classification prior to 2000 . Furthermore, since these patients were treated using different protocols, this figure seems misleading. Some, more aggressively behaving relapsing lesions have also been described [29]. The patient described in this paper is, to the best of our knowledge, the longest follow-up reported presenting with radiographic progression at 13 years and a clinical progression at 18 years.

Current day guidelines as to the treatment of adult medulloblastoma define surgical resection of the lesion as the first line treatment. According to Brandes et al., low-risk patients with no residual disease should receive 
Table 2. Review of the literature, presumptive cases of liponeurocytoma: The clinical, histo-pathological and follow-up data.

\begin{tabular}{|c|c|c|c|c|c|c|c|c|c|c|c|}
\hline \multirow{2}{*}{ No } & \multirow{2}{*}{ Age } & \multirow{2}{*}{ Sex } & \multirow{2}{*}{ Site } & \multicolumn{2}{|c|}{ Immunostaining } & \multirow{2}{*}{$\mathrm{Pi} \%$} & \multicolumn{2}{|r|}{ Tx. } & \multirow{2}{*}{ Follow-up } & \multicolumn{2}{|r|}{ Reference } \\
\hline & & & & Adi & Tc & & $\mathrm{S}$ & RT & & Year & Authors \\
\hline 1 & 44 & M & $\begin{array}{l}\text { Cerebellar } \\
\text { hemisphere }\end{array}$ & - & - & - & + & - & $\begin{array}{l}\text { D } 18 \text { hours after } \\
\text { surgery }\end{array}$ & 1978 & $\begin{array}{l}\text { Bechtel } \\
\text { et al. [5] }\end{array}$ \\
\hline 2 & 42 & M & $\begin{array}{l}\text { Lt.Cerebellar } \\
\text { hemisphere }\end{array}$ & $\begin{array}{c}\mathrm{GFAP}(+), \\
\operatorname{Vim}(+), \mathrm{S} 100(+)\end{array}$ & $\begin{array}{c}\operatorname{GFAP}(+), \mathrm{NSE}(+) \\
\mathrm{S} 100(+)\end{array}$ & - & + & - & A at 5 years & 1991 & $\begin{array}{l}\text { Chimelli } \\
\text { et al. [12] }\end{array}$ \\
\hline 3 & 49 & $\mathrm{~F}$ & Vermis & NA & $\begin{array}{l}\text { Syn(+), Leu-7(+), } \\
\text { GFAP(-), NF(-) }\end{array}$ & - & + & - & A at 5 years & 1993 & $\begin{array}{l}\text { Davis et al. } \\
\quad[13]\end{array}$ \\
\hline 4 & 53 & M & $\begin{array}{l}\text { Vermis, bilateral } \\
\text { extension }\end{array}$ & NA & $\begin{array}{l}\text { Syn(+),Leu-7(+), } \\
\text { GFAP(-), NF(-) }\end{array}$ & - & + & 54 Gy & $\mathrm{D}$ at 6 monthes & 1993 & $\begin{array}{l}\text { Davis et al. } \\
\quad \text { [13] }\end{array}$ \\
\hline 5 & 50 & $\mathrm{~F}$ & $\begin{array}{l}\text { Cerebellar } \\
\text { hemisphere }\end{array}$ & GFAP $(+)$ & $\begin{array}{c}\operatorname{Syn}(+), \operatorname{NSE}(+), \\
\text { PGP-9.5(+), } \\
\text { DES }(+) \mathrm{F}\end{array}$ & $<1$ & + & - & A at 4 years & 1993 & $\begin{array}{c}\text { Ellison et al. } \\
\quad[27]\end{array}$ \\
\hline 6 & 37 & M & $\begin{array}{l}\text { Lt. Cerebellar } \\
\text { hemisphere }\end{array}$ & GFAP(+) & $\begin{array}{c}\text { Syn }(+), N F(-), \\
\operatorname{GFAP}(+) F\end{array}$ & $<1$ & + & - & $\begin{array}{l}\text { R at } 10 \text { years, } \\
\text { Reop. at R, D } 1 \\
\text { year post-op. }\end{array}$ & 1996 & $\begin{array}{l}\text { Giangaspero } \\
\text { et al. [28] }\end{array}$ \\
\hline 7 & 36 & F & $\begin{array}{l}\text { Lt. Cerebellar } \\
\text { hemisphere }\end{array}$ & $\operatorname{GFAP}(+)$ & $\begin{array}{l}\text { Syn(+), NF(-) } \\
\text { GFAP(+)F, }\end{array}$ & $<1$ & + & - & $\begin{array}{l}\mathrm{R} \text { at } 10 \text { years, } \\
\text { Reop, } 2^{\text {nd }} \mathrm{R} \text { at } \\
\text { 5years, Reop. A. }\end{array}$ & 1996 & $\begin{array}{c}\text { Giangaspero et } \\
\text { al. }[28]\end{array}$ \\
\hline 8 & 57 & $\mathrm{~F}$ & Vermis & GFAP(+) & $\begin{array}{c}\operatorname{Syn}(+), N F(-), \\
\operatorname{GFAP}(+) F\end{array}$ & $<1$ & + & 60 Gy & $\begin{array}{c}\text { AAW after } 2 \\
\text { years }\end{array}$ & 1996 & $\begin{array}{c}\text { Giangaspero et } \\
\text { al. }[28]\end{array}$ \\
\hline 9 & 48 & $\mathrm{~F}$ & $\begin{array}{l}\text { Rt. Cerebellar } \\
\text { hemisphere }\end{array}$ & $\begin{array}{l}\operatorname{Syn}(+), \operatorname{NSE}(+) \\
\text { MAB-2(+) }\end{array}$ & $\begin{array}{l}\text { Syn }(+), \text { GFAP(+), } \\
\text { NSE(+), S100(+), } \\
\text { MAP-2(+), P53(-) }\end{array}$ & $<1$ & + & 50 Gy & A at 3.5 years & 1996 & $\begin{array}{l}\text { Söylemezoğlu } \\
\text { et al. [15] }\end{array}$ \\
\hline 10 & 53 & M & Lt. CPA & $\begin{array}{l}\operatorname{Syn}(+), \operatorname{NSE}(+), \\
\text { MAB-2(+) }\end{array}$ & $\begin{array}{c}\text { Syn }(+), \operatorname{GFAP}(+), \\
\text { S100(+),P53(-),M } \\
\text { AP-2(+), NF(-), } \\
\text { NSE }(+),\end{array}$ & $<5$ & + & - & $\begin{array}{l}\mathrm{R} \text { at } 12 \text { years, } \\
\text { Reop., A. }\end{array}$ & 1996 & $\begin{array}{l}\text { Söylemezoğlu } \\
\text { et al. [15] }\end{array}$ \\
\hline 11 & 59 & $\mathrm{~F}$ & Lt. CPA & $\begin{array}{l}\text { Syn }(+), \operatorname{NSE}(+), \\
\text { MAB-2(+) }\end{array}$ & $\begin{array}{c}\operatorname{Syn}(+), \operatorname{GFAP}(+), \\
\text { S100(+), P53(-), } \\
\operatorname{MAP}-2(+), \operatorname{NF}(-), \\
\operatorname{NSE}(+),\end{array}$ & $<3$ & + & $\begin{array}{l}55 \mathrm{~Gy} \\
24 \mathrm{~Gy}\end{array}$ & AAW at 5 years. & 1996 & $\begin{array}{l}\text { Söylemezoğlu } \\
\text { et al. [15] }\end{array}$ \\
\hline 12 & 55 & M & $\begin{array}{l}\text { Vermis and Rt. } \\
\text { Cerebellar } \\
\text { hemisphere }\end{array}$ & $\begin{array}{l}\text { S100(+)F, } \\
\operatorname{Vim}(+)\end{array}$ & $\begin{array}{c}\operatorname{Syn}(+), \operatorname{S} 100(+), \\
\operatorname{NSE}(+), \operatorname{GFAP}(+)\end{array}$ & $<1$ & + & - & A at 8 months & 1997 & $\begin{array}{c}\text { Orlandi et al. } \\
{[16]}\end{array}$ \\
\hline 13 & 67 & $\mathrm{~F}$ & Vermis & $\begin{array}{c}\text { Syn }(+) \\
\text { GFAP }(+) \\
\text { S100(+) }\end{array}$ & $\begin{array}{c}\operatorname{Syn}(+), \operatorname{S100}(+) \\
\operatorname{NSE}(+), \operatorname{GFAP}(+)\end{array}$ & $<1$ & + & - & D post-op. & 1998 & $\begin{array}{l}\text { Compora } \\
\text { et al. }\end{array}$ \\
\hline 14 & 28 & $\mathrm{~F}$ & Vermis & & & & & & $\mathrm{D}$ at 4 years & & \\
\hline 15 & 23 & M & Hemisphere & & & & & & $D$ at 7 years & & \\
\hline $\begin{array}{l}16 \\
17\end{array}$ & $\begin{array}{l}30 \\
9\end{array}$ & $\begin{array}{l}\mathrm{M} \\
\mathrm{M}\end{array}$ & $\begin{array}{l}\text { Vermis } \\
\text { Vermis }\end{array}$ & $\begin{array}{c}\operatorname{Vim}(+) \\
\text { KO-1(+), } \\
\text { CR3/43(+) }\end{array}$ & NF/MAP-2(+) & $\begin{array}{l}19.5 \sim \\
40.5\end{array}$ & + & + & $\begin{array}{l}\mathrm{D} \text { at post-op. } \\
\mathrm{D} \text { at } 5 \text { years }\end{array}$ & 2000 & $\begin{array}{l}\text { Giordana } \\
\text { et al. }[14]\end{array}$ \\
\hline 18 & 11 & M & Vermis & & & & & & $D$ at 2 years & & \\
\hline 19 & 4 & $\mathrm{~F}$ & Hemisphere & & & & & & $\mathrm{D}$ at post-op. & & \\
\hline 20 & 38 & M & Rt.hemisphere & NA & Syn $(+)$, GFAP $(-)$ & low & + & - & A at 15 months & 2001 & $\begin{array}{l}\text { Alkadhi } \\
\text { et al. [17] }\end{array}$ \\
\hline 21 & 66 & M & Lt.hemisphere & NA & NA & 3 & + & $36 \mathrm{~Gy} *$ & A at 6 months & 2001 & $\begin{array}{l}\text { Jackson } \\
\text { et al. [19] }\end{array}$ \\
\hline 22 & 61 & M & Rt.hemisphere & NA & $\begin{array}{c}\text { Syn }(+), \text { NSE }(+), \\
\text { GFAP }(+), \text { P53(+), } \\
\text { NF }(+)\end{array}$ & F & + & - & NA & 2001 & $\begin{array}{l}\text { Taddei } \\
\text { et al. [9] }\end{array}$ \\
\hline
\end{tabular}




\begin{tabular}{|c|c|c|c|c|c|c|c|c|c|c|c|}
\hline 23 & 6 & $\mathrm{~F}$ & Vermis & $\begin{array}{c}\operatorname{Syn}(+), \operatorname{S} 100(+), \\
\text { GFAP }(-)\end{array}$ & $\operatorname{Syn}(+), \operatorname{S} 100(+)$ & 33.3 & + & + & $\begin{array}{c}\text { Chemotherapy tx. } \\
\text { As well, A at } 6 \\
\text { months }\end{array}$ & 2002 & $\begin{array}{l}\text { Sharma } \\
\text { et al. }\end{array}$ \\
\hline 24 & 53 & $\mathrm{~F}$ & Rt. hemisphere & $\begin{array}{c}\operatorname{GFAP}(+), \\
\operatorname{Vim}(+), \mathrm{NSE}(+)\end{array}$ & $\operatorname{Syn}(+), \operatorname{NSE}(+)$ & $<5$ & + & + & A at 1 year & 2002 & $\begin{array}{l}\text { Montagna } \\
\text { et al. }\end{array}$ \\
\hline 25 & 49 & $\mathrm{~F}$ & $\begin{array}{c}\text { Vermis, } \\
\text { Intra-ventricular }\end{array}$ & Syn $(+)$ weak & $\begin{array}{l}\operatorname{Syn}(+), \operatorname{S} 100(+), \\
\operatorname{GFAP}(+), \text { P53(-) }\end{array}$ & $<1$ & + & + & $\mathrm{D}$ at 19 months & 2003 & $\begin{array}{l}\text { Aker } \\
\text { et al. [6] }\end{array}$ \\
\hline 26 & 45 & $\mathrm{~F}$ & Rt. hemisphere & NA & $\begin{array}{c}\operatorname{GFAP}(+), \operatorname{NSE}(+), \\
\operatorname{CEA}(-)\end{array}$ & $<2.5$ & + & $\begin{array}{c}3.6 \\
\text { Gy** }\end{array}$ & $\begin{array}{l}\text { Chemotherapy tx., } \\
\text { AAW at } 3 \text { years. }\end{array}$ & 2003 & $\begin{array}{l}\text { Elshihabi } \\
\text { et al. [3] }\end{array}$ \\
\hline 27 & 38 & $\mathrm{~F}$ & Lt. hemisphere & NA & NA & NA & + & NA & NA & 2003 & $\begin{array}{l}\text { Amina } \\
\text { et al. [7] }\end{array}$ \\
\hline 28 & 64 & M & Rt. hemisphere & $\begin{array}{c}\mathrm{NSE}(+), \mathrm{NF}(+), \\
\operatorname{GFAP}(+)\end{array}$ & $\begin{array}{c}\mathrm{NSE}(+), \mathrm{NF}(+), \\
\operatorname{GFAP}(-)\end{array}$ & 20 & + & $15.4 \mathrm{~Gy}$ & $\begin{array}{c}\text { R at } 3.5 \text { years, } \\
\text { Reop. A at } 5 \\
\text { months }\end{array}$ & 2005 & $\begin{array}{l}\text { Buccoliero } \\
\text { et al. [30] }\end{array}$ \\
\hline 29 & 39 & M & $\begin{array}{c}\text { Vermis, } \\
\text { Intra-ventricular }\end{array}$ & NA & $\begin{array}{c}\operatorname{NSE}(+), \operatorname{Syn}(+) \\
\operatorname{GFAP}(-), \operatorname{NFP}(-)\end{array}$ & $<1$ & + & - & A at 45 days & 2006 & $\begin{array}{l}\text { Bayar } \\
\text { et al. [8] }\end{array}$ \\
\hline
\end{tabular}

M/F - male / female, Adi - adipocytes, Tc - Tumor cell, S - surgery, RT - radiotherapy, F - Focal, Pi - Proliferation index, D - Deceased, A - alive, AAW alive and well, R - recurrence, NA - not available, GFAP - Glial fibrillar acid protein, NSE - neural specific enolase, Syn - synaptophysin, Vim - vimentin. CPA - cerebellopontine angle, Reop -reoperation, *36 Gy for the entire brain, 56 Gy boost to posterior fossa; **3.6 Gy to the spine and whole brain, 1,800 cGy boost dose to the posterior fossa. The patient also received chemotherapy for 12 months, consisting of cisplatin, PCNU, and vincristine.

craniospinal radiation of $36 \mathrm{~Gy}$ and a boost to the posterior fossa of about 18 Gy. High-risk patients with residual or metastatic disease should receive additional chemotherapy with cisplatin, etoposide, and cyclophosphamide [2,31]. Out of the twenty-nine patient described, four pediatric patients operated on underwent a GTR. Proliferation index was $>3 \%$ in all children, all received radiotherapy following different protocols, one patient received chemotherapy. Prognosis was dismal, with most children deceased during the follow-up ( 3 out of 4 patients). Of the remaining 25 patients described, 12 received radiotherapy following the operation (described as GTR for all) following different protocols. Proliferation index in this group was $>3 \%$ in 7 patients (58\%), as compared to $15 \%$ in those not receiving radiotherapy. Only a single recurrence is described in the irradiated group (as compared to 3 in those not receiving radiotherapy), although a significantly higher mortality rate was noted in those patients receiving radiotherapy (8 patients versus 3 in those not irradiated). This can be attributed to iatrogenic irradiation induced pathology, concurrent illnesses, a more aggressive tumor behavior or a combination of all of the above [Table 2]. Trying to construct a Kaplan-Meier (KM) survival curve is somewhat problematic, still supporting the same conclusions [Table 1, Figure 5]. The main weakness of the KM curve stems from the small sample size, inherent to this tumor. Of the eleven patients not receiving radiotherapy, three died during the follow-up. Of the sixteen patients irradiated, eight died during the follow-up. Incomplete data required for the $\mathrm{KM}$ curve construction exist for two patients [no. \#22 and \#27 in Table 2]. The KM curve, under the caveats mentioned, supports the argument that radiotherapy and accompanying morbidity is not proven in the liponeurocytoma patient, actually resulting in shorter survival.

The indolent clinical behavior and suspected natural history of the cerebellar liponeurocytoma, manifesting as a slowly growing lesion only locally recurrent, raises doubts about the appropriateness of adjuvant radiotherapy and/or chemotherapy. Such an aggressive treatment approach, having a high biological toil and horrible iatrogenic side effects [8] has not been proven effective enough to our opinion, given any outcome parameter as an indicator. According to Kleihues [1], the prognosis is favorable if the MIB-1 index is in the range of $1 \% \sim 3 \%$ and aggressive adjuvant therapy is not mandatory. There have been no reports of spinal drop metastases in the literature and it is therefore reasonable to avoid spinal radiation [8]. In our patient, after reviewing current literature, a joint multidisciplinary staff comprising of neurosurgeons, neuro-oncologists, neuroradiologists and neuropathologists has recommended pursuing a conservative treatment approach with close clinical and radiological follow-up.

\section{Conclusions}

The small number of patients reported with this type of lesion, limits our understanding of this tumor's natural history. Most of the information available from case reports indicates that this tumor has a benign biological behavior and prognosis in adults. Thus, expectant treatment with close follow-up seems both prudent and sufficient. We suggest that a patient with established liponeurocytoma, who underwent a GTR, and in which the tu- 


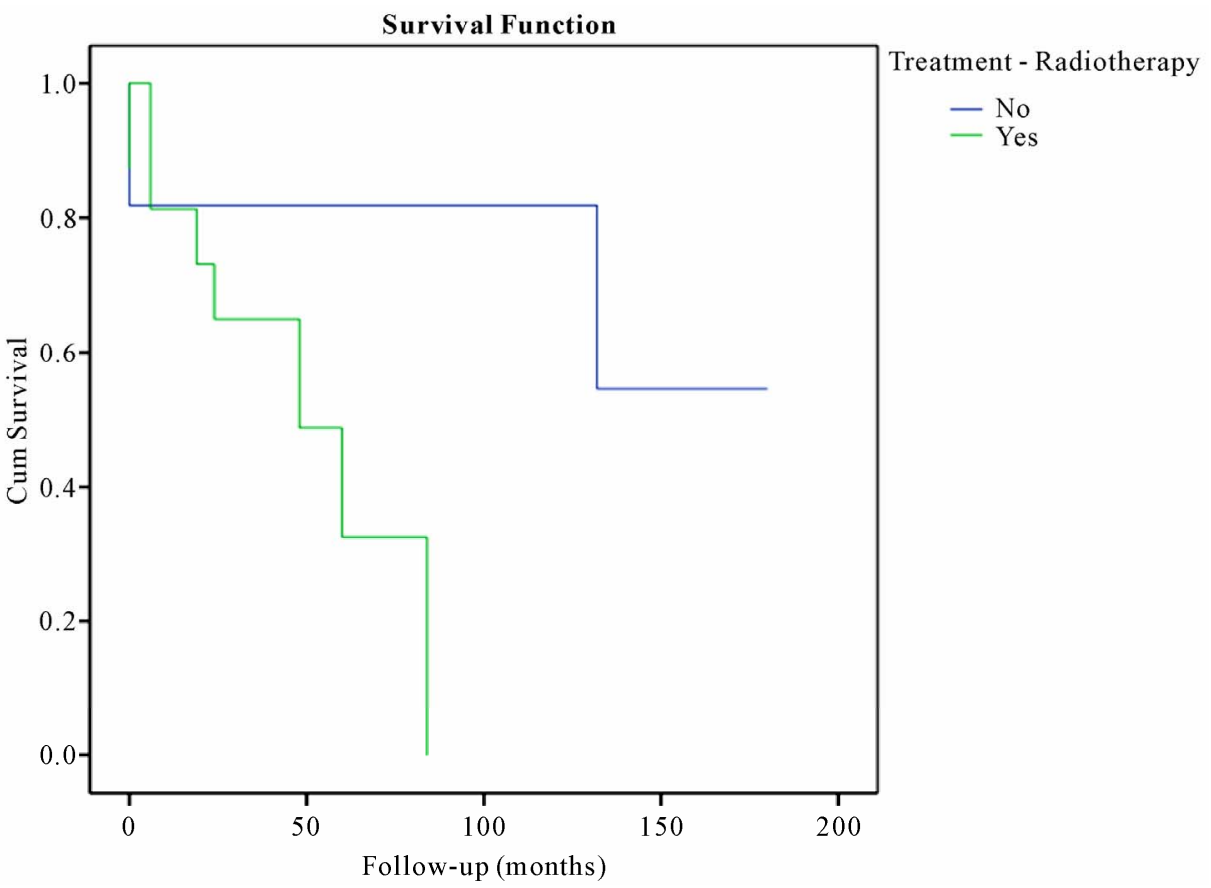

Figure 5. Kaplan-Meier survival curve by months, as influenced by treatment with radiotherapy.

mor shows a low proliferation index, can undergo a yearly MRI and follow-up with no additional adjuvant care. The patient presented underwent a GTR in both operations, received no adjuvant treatment during the last 18 years, hence presenting the natural history of this tumor after a surgical intervention and spared the sideeffects of un-necessary radiotherapy or chemotherapy.

\section{References}

[1] P. Kleihues and G. F. Egnaczyk, "Lipomatous Medulloblastoma," In: P. Kleihues and W. K. Cavenee, Eds., Pathology and Genetics of Tumors of the Nervous System, 1997, pp. 107-109.

[2] A. Peraud, J. C. Tonn, T. R. James, et al., "Medulloblastoma-PNET, Craniopharyngioma Adult Tumors of Pediatric Origin," Oncology of CNS Tumors, Berlin Heidelberg, Springer, 2010, pp. 189-194.

doi:10.1007/978-3-642-02874-8-10

[3] S. Elshihabi, M. Husain and M. Linskey, "Lipomatous Medulloblastoma: A Rare Adult Tumor Variant with a Uniquely Favorable Prognosis," Surgery Neurology, Vol. 60 , No. 6, 2003, pp. 566-570. doi:10.1016/S0090-3019(03)00192-7

[4] C. Sarkar, P. Pramanik, A. K. Karak, et al., "Are Childhood and Adult Medulloblastomas Different? A Comparative Study of Clinicopathological Features, Proliferation Index and Apoptotic Index," Journal of Neurooncology, Vol. 59, 2002, pp. 49-61. doi:10.1023/A:1016357731363

[5] J. T. Bechtel, J. M. Patton and Y. Takei, "Mixed Mesen- chymal and Neuroectodermal Tumor of the Cerebellum," Acta Neuropathology, Vol. 41, 1978, pp. 261-263. doi:10.1007/BF00690447

[6] F. V. Aker, S. Ozkara, P. Eren, et al., "Cerebellar Liponeurocytoma/Lipidized Medulloblastoma," Journal of Neurooncology, Vol. 71, 2005, pp. 53-59. doi:10.1007/s11060-004-9172-4

[7] M. Amina, B. Saadia, N. Kais, et al., "Cerebellar Liponeurocytoma: A Case Report and Review of the Literature," Pathologica, Vol. 95, 2003, pp. 456-459.

[8] M. A. Bayar, H. Pulat, H. Celik, et al., "Cerebellar Liponeurocytoma: A Case Report," Turkish Neurosurgery, Vol. 16, 2006, pp. 150-153.

[9] G. L. Taddei, A. M. Buccoliero, A. Caldarella, et al., "Cerebellar Liponeurocytoma: Immunohistochemical and Ultrastructural Study of a Case," Ultrastructural Pathology, Vol. 25, No. 1, 2001, pp. 59-63. doi: $10.1080 / 019131201300004690$

[10] S. Horstmann, A. Perry, G. Reifenberger, et al., "Genetic and Expression Profiles of Cerebellar Liponeurocytomas," Brain Pathology, Vol. 14, 2004, pp. 281-289. doi:10.1111/j.1750-3639.2004.tb00065.x

[11] D. N. Louis, H. Ohgaki, O. D. Wiestler, et al., "The 2007 WHO Classification of Tumours of the Central Nervous System," Acta Neuropathology, Vol. 114, 2007, pp. 97-109. doi:10.1007/s00401-007-0243-4

[12] L. Chimelli, M. D. Hahn and H. Budka, "Lipomatous Differentiation in a Medulloblastoma," Acta Neuropathology, Vol. 81, No. 4, 1991, pp. 471-473. doi:10.1007/BF00293470

[13] D. G. Davis, D. Wilson, M. Schmitz, et al., "Lipidized Medulloblastoma in Adults," Hum Pathology, Vol. 24, 
1993, pp. 990-995 doi:10.1016/0046-8177(93)90113-U

[14] M. T. Giordana, P. Schiffer, A. Boghi, et al., "Medulloblastoma with Lipidized Cells Versus Lipomatous Medulloblastoma," Clinical Neuropathology, Vol. 19, 2000, pp. 273-277.

[15] F. Soylemezoglu, D. Soffer, B. Onol, et al., "Lipomatous Medulloblastoma in Adults: A Distinct Clinicopathological Entity," American Journal of Surgical Pathology, Vol. 20, 1996, pp. 413-418. doi:10.1097/00000478-199604000-00003

[16] A. Orlandi, B. Marino, M. Brunori, et al., "Lipomatous medulloblastoma," Clinical Neuropathology, Vol. 16, 1997, pp. 175-179.

[17] H. Alkadhi, M. Keller, S. Brandner, et al., "Neuroimaging of Cerebellar Liponeurocytoma: A Case Report," Journal of Neurosurgery, Vol. 95, 2001, pp. 324-331. doi:10.3171/jns.2001.95.2.0324

[18] F. Cacciola, R. Conti, G. L. Taddei, et al., "Cerebellar Liponeurocytoma: A Case Report with Considerations on Prognosis and Management," Acta Neurochirurgica, Wien, Vol. 144, 2002, pp. 829-833. doi: $10.1007 / \mathrm{s} 007010200082$

[19] T. R. Jackson, W. F. Regine, D. Wilson, et al., "Cerebellar Liponeurocytoma: A Case Report and Review of the Literature," Journal of Neurosurgery, Vol. 95, 2001, pp. 700-703. doi:10.3171/jns.2001.95.4.0700

[20] J. J. Kepes, L. J. Rubinstein and L. F. Eng, "Pleomorphic Xanthoastrocytoma: A Distinctive Meningocerebral Glioma of Young Subjects with Relatively Favorable Prognosis," Cancer, Vol. 44, 1979, pp. 1839-1852. doi:10.1002/1097-0142(197911)44:5<1839::AID-CNCR $\underline{2820440543>3.0 . \mathrm{CO} ; 2-0}$

[21] J. M. Roda and M. Gutierrez-Molina, "Multiple Intraspinal Low-Grade Astrocytomas Mixed with Lipoma Astrolipoma: A Case Report," Journal of Neurosurgery, Vol. 82, 1995, pp. 891-894.

[22] M. M. Ruchoux, J. J. Kepes, P. Dhellemmes, et al., "Lipomatous Differentiation in Ependymomas: A Report of Three Cases and Comparison with Similar Changes Reported in Other Central Nervous System Neoplasms of Neuroectodermal Origin," American Journal of Surgical
Pathology, Vol. 22, 1998, pp. 338-346. doi:10.1097/00000478-199803000-00009

[23] D. S. Russel and L. J. Rubenstein, "Tumors of Central Neuroepithelial Origin," In: D. S. Russel and L. J. Rubenstein, Eds., Pathology of Tumors of the Nervous System, 6th Edition, Edward Arnold, London, 1998, pp. 460-470.

[24] L. Selassie, R. Rigotti, J. J. Kepes, et al., “Adipose Tissue and Smooth Muscle in a Primitive Neuroectodermal Tumor of Cerebrum," Acta Neuropathology, Vol. 87, 1994, pp. 217-222. doi:10.1007/BF00296193

[25] A. Akhaddar, I. Zrara, M. Gazzaz, et al., "Cerebellar Liponeurocytoma (Lipomatous Medulloblastoma)," Journal of Neuroradiology, Vol. 30, 2003, pp. 121-126.

[26] C. H. Alleyne, S. Hunter, J. J. Olson, et al., "Lipomatous Glioneurocytoma of the Posterior Fossa with Divergent Differentiation: A Case Report," Neurosurgery, Vol. 42, 1998, PP. 639-643.

[27] D. W. Ellison, S. C. Zygmunt and R. O. Weller, "Neurocytoma/Lipoma (Neurolipocytoma) of the Cerebellum," Neuropathol Application Neurobiology, Vol. 19, 1993, pp. 95-98. doi:10.1111/j.1365-2990.1993.tb00410.x

[28] F. Giangaspero, G. Cenacchi, F. Roncaroli, et al., "Medullocytoma (Lipidized Medulloblastoma): A Cerebellar Neoplasm of Adults with Favorable Prognosis," American Journal of Surgical Pathology, Vol. 20, 1996, pp. 656-664. doi:10.1097/00000478-199606000-00002

[29] M. D. Jenkinson, J. J. Bosma, P. D. Du, et al., "Cerebellar Liponeurocytoma with an Unusually Aggressive Clinical Course: A Case Report," Neurosurgery, Vol. 53 , 2003, pp. 1425-1427. doi:10.1227/01.NEU.0000093430.61239.7E

[30] A. M. Buccoliero, A. Caldarella, S. Bacci, et al., "Cerebellar Liponeurocytoma: Morphological, Immunohistochemical, and Ultrastructural Study of a Relapsed Case," Neuropathology, Vol. 25, 2005, pp. 77-83. doi:10.1111/j.1440-1789.2004.00574.x

[31] A. A. Brandes, M. Ermani, P. Amista, et al., "The Treatment of Adults with Medulloblastoma: A Prospective Study," International Journal of Radiation Oncology Biology Physics, Vol. 57, No. 3, 2003, pp. 755-761. doi:10.1016/S0360-3016(03)00643-6 